\title{
Water Quality Management in the Wildlife Lodge Industry: A Multiple Case Study in South Africa, Namibia and Botswana
}

\author{
By Jacobus J. Grobler ${ }^{*} \&$ Kevin F. Mearns ${ }^{\dagger}$
}

\begin{abstract}
Water is one the most important substances on earth as all living organisms require it to survive. It is a vital component for human survival in the form of direct consumption as well as food production. Water is equally important for the tourism industry as water is utilised throughout the tourism value chain for the provision of services to guests. Many tourism lodges in the wildlife lodge industry in South Africa, Namibia and Botswana are in remote areas where little to no infrastructure exists. These lodges are dependent on natural water sources such as rivers, dams and boreholes to supply their water demands. Another significant aspect of the lodges is that staff has to reside on the property due to the lack of nearby housing, roads and public transport. One of the challenges for the lodges is that residing staff have to use the water for domestic purposes and therefore managers have to ensure that the water quality is of such standard that it does not pose health risks for staff and guests. Water quality management in the wildlife lodge industry is one of the most important, if not the most important aspect of the industry. The authors obtained secondary data in the form of water quality analysis done at the lodges across these three countries. The study investigated whether lodges did water quality analysis at source, tap and wastewater discharge. Furthermore, the results of the water quality analysis were subjected to their adherence to the relevant water quality standards of each country. These results provided important information regarding the comprehensiveness of the water quality analysis. The frequency of water quality testing was also determined as this provides a measure of the adherence of lodges to the legal, concession or company requirements as stated in various standards and procedures. The authors concluded that the current systems can be improved to ensure that water quality is managed more sustainably in the wildlife industry. The biggest concern relates to wastewater discharge, where very little water quality at points of discharge is available; this has the potential to cause pollution and ecosystem degradation.
\end{abstract}

Keywords: Tourism, Water Quality Management, Wildlife Lodge Industry.

\section{Introduction}

"When the well's dry, we know the worth of water" (Franklin 1746).

This was the aphorism published by Benjamin Franklin in 1746 from his Poor Richard's almanac. Since then, the world population increased from an estimate 706 million to 7.6 billion in 2017, raising the demand for water immensely. A common saying recently is: "you can't wash dirty water", while Ismail Serageldin (2009), president of the World Bank (1992 -2000) stated in 1995 at a conference in

*Post-Graduate Student, University of South Africa, South Africa.

†Professor, University of South Africa, South Africa. 
Stockholm, Sweden: "The wars of the $21^{\text {st }}$ century will be fought over water" (Gleditsch 1997).

The tourism industry across the world requires water for basic human consumption, irrigation of gardens and golf courses, preparation of food and drinks, making snow for winter sports and general water activities such as swimming or motorised water sports (Gössling et al. 2012). It is of utmost importance that tourism ventures improve their water management and maximise the water available to them. The wildlife lodge industry in South Africa, Namibia and Botswana are no different and depend on water for their existence. In many cases, the livelihood and survival of local communities rely on the industry to provide a source of income as well as other social benefits to these communities.

Water quality management in the wildlife lodge industry involves all the processes and procedures from the abstraction point to discharging back into the environment. This will include purification systems, water recycling, sewage treatment and finally discharging back into the environment. A challenge that the lodges face is access to laboratories to conduct frequent water quality analyses. This, with other logistical challenges to do water quality analyses raises the cost of water testing and also consumes human resources to do so (W. Ozorio, Personal communication, February 12, 2017). Since the lodges source their water from natural resources, water has to be treated before it can be utilised by staff or guests. Due to the logistical challenges a major concern is that water is discharged into the environment without knowing the quality and the effect the water might have on the environment.

In this study the authors will investigate the current water quality management systems that are implemented at the lodges. The authors will determine the frequency and significance of water quality testing as well as the physical quality of the water at the lodges. The authors will make recommendations regarding the water quality management systems which would lead to continuous improvement of current systems.

\section{Literature Study}

Humans simply cannot live without water as we need water for basic consumption, hydration, and food preparation and hygiene purposes (Howard and Bartram 2003). Tourism activities contribute to water consumption and can be partially responsible for depleting water sources. This could lead to starvation in local communities, poor hygiene and health concerns as well as accelerating the spread of diseases, dehydration and ultimately death. Other health problems such as cancer, anaemia, sleeping disorders, poor appetite, constipation, vomiting, kidney problems and abdominal pain are diseases related to poor water quality (Khan et al. 2013). It is thus of utmost importance that tourism ventures preserve good quality freshwater as the well-being of staff and guests depend on the availability of good quality freshwater.

Poor water quality does not only affect human health but can also impact on the environment. Wastewater with a high nutrient content can cause eutrophication 
(Gössling et al. 2015). This can result in algae blooms, including blue-green algae which is toxic to animals and can result in death. Wastewater with a high Chemical Oxygen Demand (COD) will reduce the dissolved oxygen in water courses, reducing precious oxygen available for aquatic animals to survive. A rapid decrease in oxygen levels in freshwater eco-systems could lead to a massive loss in biodiversity.

Tourism activities can also impact negatively on the quality of water increasing health problems in local communities. In Lijiang Ancient Town, China, tourist numbers increased from 2.8 millions arrivals in 2000 up to 4.6 millions in 2006. An investigation on the residents' attitudes was carried out, aimed at visually and clearly understanding the condition of water quality deterioration in the area. The results showed that the water quality from the source dropped from a grade I, which could be consumed directly by humans and animals to a grade $\mathrm{V}$, the worst grade possible. Too many tourists, inefficient management of the number of shops and their activities and the poor infrastructure construction of waste water collection and disposal has resulted in the decline of water quality (Baoying and Yuanqing 2007).

The tourism industry depends on good quality drinking water to meet tourist expectations and especially where staff lives on the premises. Tourism can impact negatively on water quality if discharge is not managed properly. Wastewater and sewage discharge may contain nutrients and other pollutants such as chlorinated pool water or chemicals used to dissolve fats and oils during cleaning and in kitchens (Kuss et al. 1990). Water quality testing and analysis are usually done by external experts or laboratories since the equipment is rather expensive and the lack of scientific knowledge of staff. Grobler and Mearns (2017) stated that water quality results can be used as management tool if used properly. The authors stated that water quality analysis should be done at the following locations for the following reasons:

- The source: It is important to know the quality of the source as this will determine the processes required to purify the water to drinking quality.

- After treatment: The water quality results will indicate whether the treatment was sufficient and if the water is fit for human consumption. Over time these results can indicate maintenance requirements such as changing of membranes, filters or other issues should water quality decrease.

- Wastewater after treatment, before discharge: This will indicate whether the wastewater and sewage treatment processes were successful and indicate the impact the discharge can have on eco-systems or water quality should it be discharged into a water course.

Water quality is mostly measured against standards or statutory regulations. In this study the authors will use the individual country's statutory requirements and national standards to measure water quality against. For South Africa the authors will use the SANS 241: 2015 Drinking water quality standard (SABS 2015) to measure drinking water quality against. For wastewater, the authors will use the 
limits as stated in the National Water Act no. 36 of 1998. For Botswana the authors will use the Botswana Bureau of Standards BOS 93:2004 (Walmsley and Patel 2011) for wastewater comparison and the BOS 32:2009 for drinking water comparisons. For Namibia the guidelines as stated in Article 140 of Act no. 1 of 1990 (Walmsley and Patel 2011) will be used to measure drinking water as well as wastewater results against. The standards for all three countries are stated in Appendix A to F individually.

\section{Study Area and Methodology}

\section{Study Area}

Lodges in South Africa, Namibia and Botswana were selected based on the availability of data. The regions from the selected lodges differs vastly from desert, swampland, coastal forest and savanna (see figure 1). The geographical locations of the lodges could possibly impact the quality of the water and could play a major part in this study. Geological features also play a major role in water quality and it is important to identify the difference in water quality from the different regions as water purifying process might need to differ to obtain a healthy standard of water for human consumption purposes.

\section{Figure 1. Study Areas}

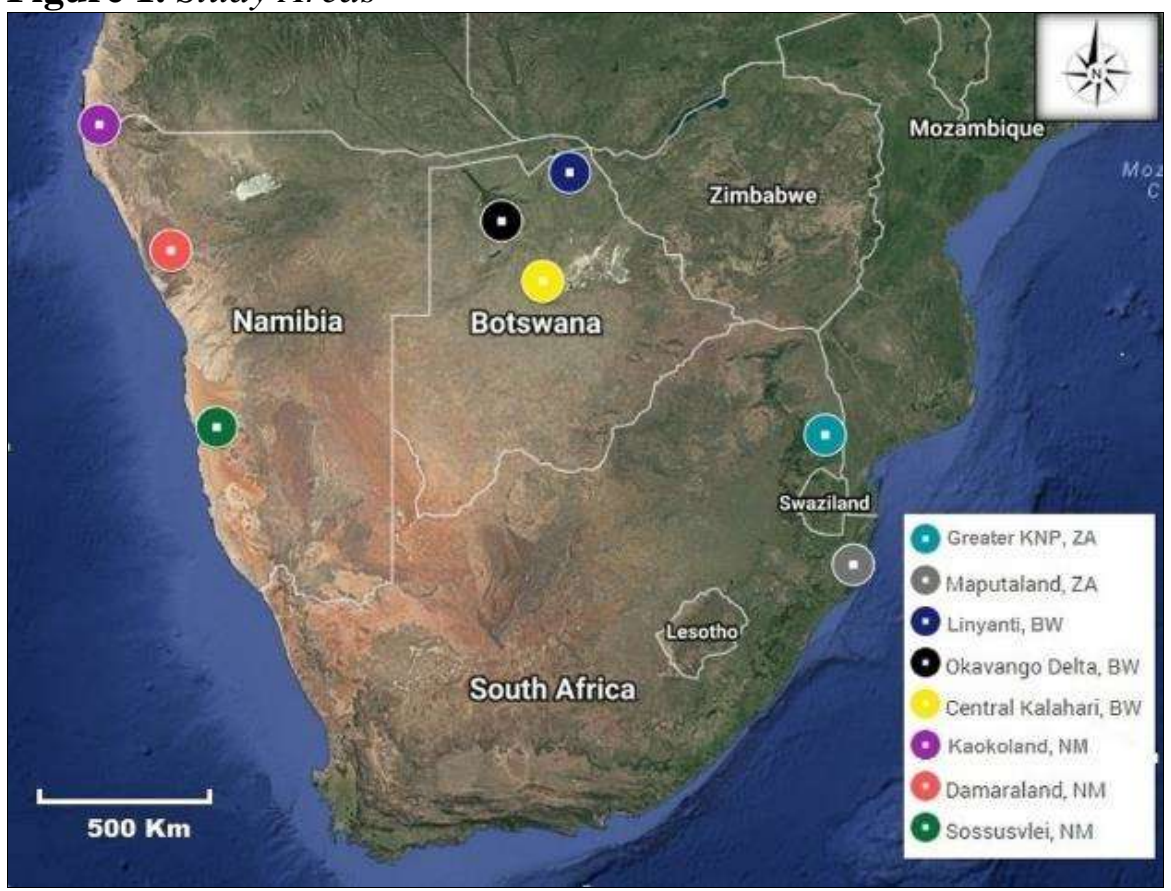

Source: Google Maps, 2017. 


\section{Methodology}

All data that was obtained was for the 24 month period from March 2015 to February 2017. All the lodge names have been changed to codes to ensure anonymity as per agreement with the research partners. The first letter in the code refers to the country in which the lodge is situated, whereas the number at the end was the number that the authors allocated to a specific lodge for identification, for example B3 will mean the third of the lodges whose data was analysed by the authors in Botswana. Information obtained from staff members at the camps will not be referenced and names will not be published. Any statements from staff members will only be referred to as: "a staff member". The reason for this approach is to protect the identity of any staff members.

The authors obtained secondary data in the form of water quality analysis done at the lodges. The first part in this section focussed on how many lodges did water quality analysis on its source, tap and wastewater discharge. The second part in this section focussed on the frequency of testing. The authors obtained annual/ monthly water quality results or reports from the lodges. Table 1 below stated how many lodges in their respective countries had water quality results of the source, tap and/or waste water discharge as well as how many lodges have not done any water quality testing.

Table 1. Water Quality Results at the Lodges

\begin{tabular}{|l|c|c|c|c|}
\hline Country & Source & Tap & Wastewater discharge & No tests \\
\hline South Africa & $4 / 8$ & $7 / 8$ & $6 / 8$ & $1 / 8$ \\
\hline Namibia & $0 / 8$ & $7 / 8$ & $0 / 8$ & $1 / 8$ \\
\hline Botswana & $5 / 15$ & $5 / 15$ & $0 / 15$ & $10 / 15$ \\
\hline All countries combined & $9 / 31$ & $19 / 31$ & $6 / 31$ & $12 / 31$ \\
\hline
\end{tabular}

Source: Author.

The water quality results were graphed and measured against the relevant countries' standards to determine if the quality complies with standard limits. Although the World Health Organisation (WHO) publish and update drinking water quality limits, most countries have their own adaption of water quality parameter limits and are often published in standards or legislation. It is therefore important to notice that the parameter limits used in this study was measured against the relevant standard or legislation of each country individually to ensure that the water quality was measured against the appropriate legislation. It is of great importance to notice this fact. A good example will be a $\mathrm{pH}$ of nine might be accepted in South Africa whereas it might not be in Botswana. It is thus advised that the limits in this study should not be used to measure legal compliance in other countries but rather be used as a guide or contrast comparisons.

\section{Results and Discussion}

Testing water at the source is an important sample point as it would determine the processes and treatment required for water to be consumed by humans at the 
lodge. It will also over a period of time indicate whether there was a decrease or increase in the water quality which could determine what amendments are required to keep water quality fit for human consumption at the lodge. As illustrated in Figure 2, the results indicate that $50 \%$ of the lodges in South Africa had water quality analyses done on their water source. In Namibia none of the lodges had water quality results at the source whereas $33 \%$ of the lodges in Botswana had water quality results on their source. This result thus states that the majority of the lodges across the three countries do not test the quality of their water source. This could have impacts on the success of the water purification and treatment processes as the treatment processes are generic rather than specific to treatment needs of the specific supply.

Figure 2. Percentage of Lodges that Conducted Water Quality Analyses at their Source

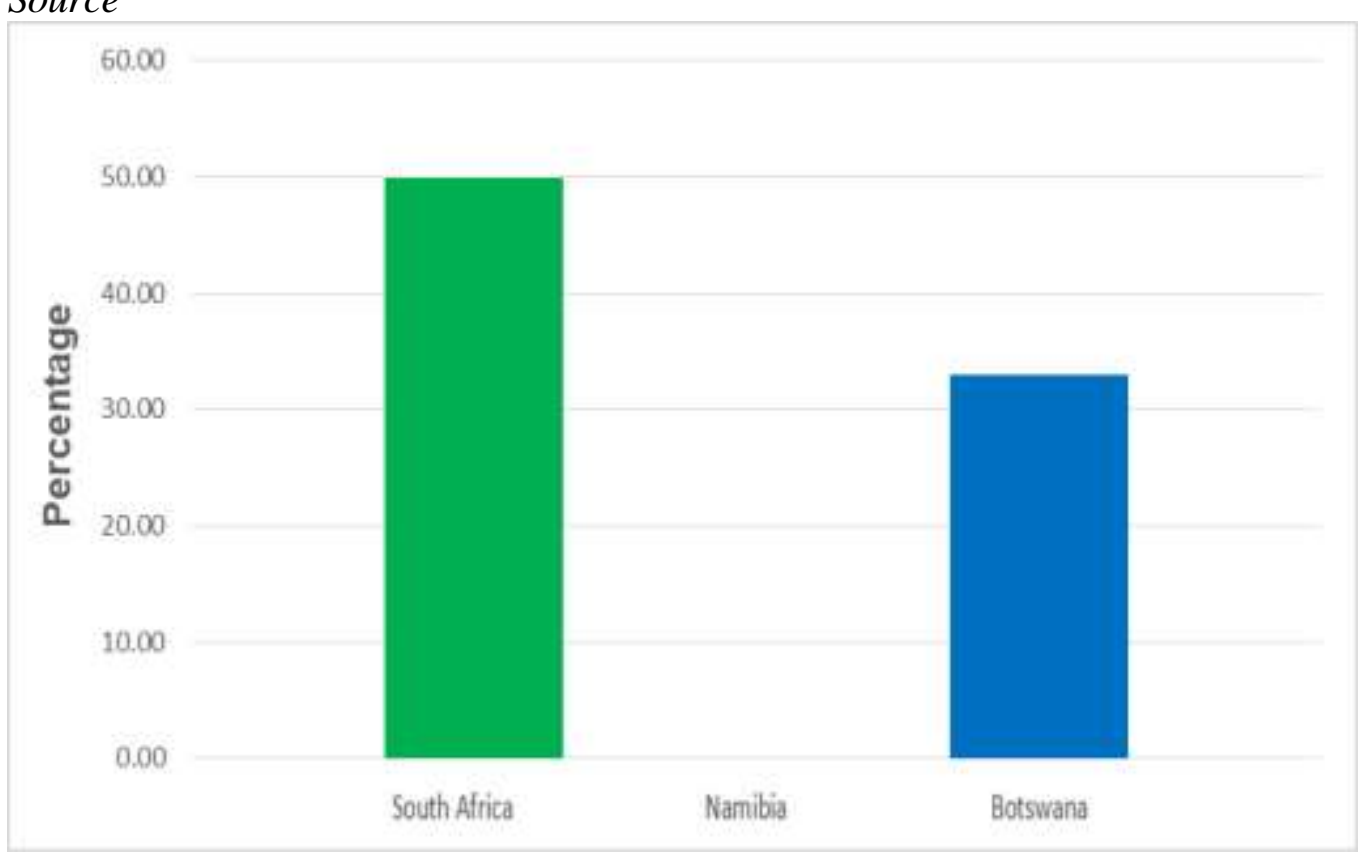

Source: Author.

Tap water is also an important sample point as this is the end point where guests and staff obtain water for their consumption. It is also an important indicator whether the treatment processes were successful and to determine if contamination occurs during the transfer of the water from the treatment plant to the end point. The results are illustrated in Figure 3.

In South Africa, $88 \%$ of the lodges had their tap water quality analysed. In Namibia $75 \%$ of the lodges had their tap water quality analysed whereas only $33 \%$ of the lodges in Botswana had done water quality analyses on their tap water. An observation at the lodges from Namibia was that $50 \%$ of the lodges had the exact same results for either two or three years in a row for all the parameters, strongly suggesting that the results were copied and pasted from the first analysis. This jeopardises the credibility of the results and the supplier. 
Wastewater is another crucial sample point as it could have negative impacts on water courses such as eutrophication. It can have negative impacts on the environment and alter micro-ecosystems due to contaminants. With regards to wastewater quality, $75 \%$ of the lodges in South Africa had done wastewater quality. None of the lodges in Namibia or Botswana had done water quality analyses on their wastewater.

Figure 3. Percentage of Lodges that Conducted Water Quality Analyses at their Tap

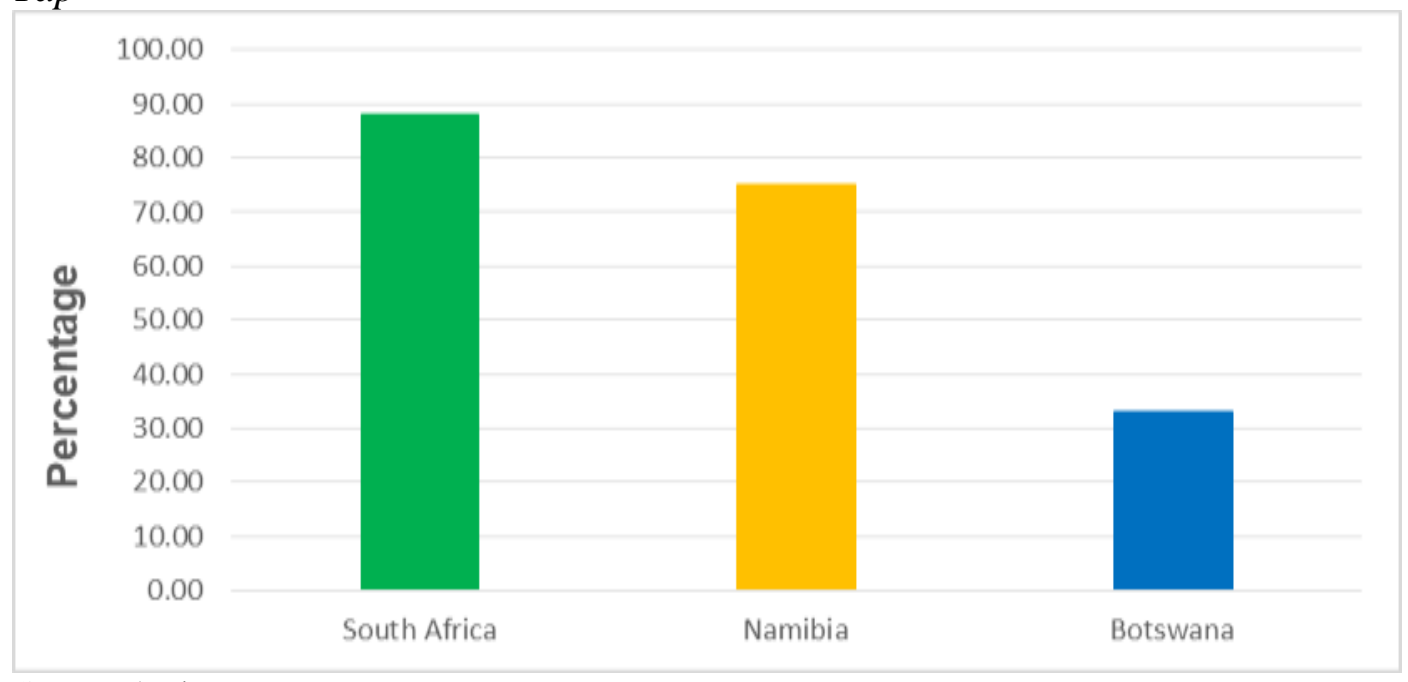

Source: Author.

The water quality results were compared against the relevant country's national water standard for drinking water and wastewater discharge. The number of parameters that were tested in the analyses was compared against the required number of parameters stated in the relevant standards. In South Africa, three different service providers were used at various lodges, each testing their own set of parameters. In Namibia, all seven lodges used the same service provider and thus the results were universal for all seven lodges. The same was applicable for the five lodges in Botswana. Table 2 below states the results of this investigation with regards to drinking water whereas Table 3 states the results with regards to wastewater discharge.

Although $88 \%$ of the lodges in South Africa had their tap water quality analysed, only $25 \%$ lodges in the country tested more than $26 \%$ of the required parameters.

All seven lodges in Namibia tested only $37 \%$ of the required parameters for drinking water. Again, these reports are quite poor due the majority of the parameters not being tested. An observation with the Namibian results is that there were no microbiological analyses, only chemical analyses. This could be due to limitations from the supplier and/or laboratory in the region. However, the exact cause why there were no microbiological analyses is not covered in this study and would require further investigation. 
Table 2. Drinking Water Parameters Tested vs Parameters Required

\begin{tabular}{|c|c|c|c|c|c|}
\hline Country & $\begin{array}{l}\text { No of } \\
\text { lodges }\end{array}$ & Standard & $\begin{array}{c}\text { Parameters } \\
\text { tested }\end{array}$ & $\begin{array}{c}\text { Parameters } \\
\text { required }\end{array}$ & $\begin{array}{c}\% \\
\text { tested }\end{array}$ \\
\hline $\begin{array}{l}\text { South } \\
\text { Africa }\end{array}$ & & SANS:241:2015 & & & \\
\hline $\begin{array}{l}\text { Service } \\
\text { provider } 1\end{array}$ & 4 & & 9 & 47 & $19 \%$ \\
\hline $\begin{array}{l}\text { Service } \\
\text { provider } 2\end{array}$ & 2 & & 35 & 47 & $74 \%$ \\
\hline $\begin{array}{l}\text { Service } \\
\text { provider } 3\end{array}$ & 1 & & 12 & 47 & $26 \%$ \\
\hline Namibia & 7 & $\begin{array}{c}\text { The Water Act } \\
\text { (56 of } 1956)\end{array}$ & 20 & 54 & $37 \%$ \\
\hline Botswana & 5 & BOS 32:2009 & 16 & 57 & $28 \%$ \\
\hline
\end{tabular}

Source: Author.

The five lodges in Botswana only tested $28 \%$ of the required parameters for drinking water. According to a staff member the lodges had their water analysed at a university in Maun by students under supervision. Not only are the results poor but the majority of the parameters are not tested, the analyses are also not done by qualified and experienced professionals which effects the credibility of the results. According to the same staff member, there are no other water quality facilities in the province. This and other logistical challenges such as the remote locations in Botswana with limited infrastructure make water quality testing near impossible. The authors verified this information on his site visits and can appreciate the effort from the lodges that attempted to have water quality tested.

Table 3. Wastewater Parameters Tested vs Parameters Required

\begin{tabular}{|l|c|c|c|c|c|}
\hline Country & $\begin{array}{c}\text { No of } \\
\text { lodges }\end{array}$ & Standard & $\begin{array}{c}\text { Parameters } \\
\text { tested }\end{array}$ & $\begin{array}{c}\text { Parameters } \\
\text { required }\end{array}$ & $\begin{array}{c}\% \\
\text { tested }\end{array}$ \\
\hline $\begin{array}{l}\text { South } \\
\text { Africa }\end{array}$ & & $\begin{array}{c}\text { National Gazette } \\
\text { No 36820, 6 Sep } \\
2013\end{array}$ & & & \\
$\begin{array}{l}\text { Service } \\
\text { provider 1 } \\
\begin{array}{l}\text { Service } \\
\text { provider 2 }\end{array}\end{array}$ & 2 & 2 & 5 & $40 \%$ \\
\hline Namibia & & $\begin{array}{c}\text { Guidelines } \\
(461 / 85)\end{array}$ & 0 & 5 & $100 \%$ \\
\hline Botswana & & BOS 93:2004 & 0 & 26 & $0 \%$ \\
\hline
\end{tabular}

Source: Author.

Of the six lodges in South Africa that tested wastewater discharge, two complied $100 \%$ with the requirements and exceeded the required amount of parameters, whereas four lodges tested $40 \%$ of the required parameters. This means that the wastewater quality results are inconclusive at these four lodges and 
that the authors could not establish whether the wastewater quality complies with legal requirements. The lodges can also not determine the efficiency of their wastewater plant as there is no results to indicate that the plant is operating successfully.

The importance of water quality has been well defined earlier in this study. In this section of the paper the authors selected eight important parameters from the water quality reports from the lodges in all three countries. The authors also stated the associated aesthetic and human health effects from each microbial-, micro- and macro-determinant. The results were also measured against the corresponding country's standard or guideline to determine if the water quality is suitable for human consumption. Although the Namibian guideline for drinking water has four categories, only category A was used in the figures below. Where a result exceeded the limit of category A, the authors referred to the other categories to determine whether the water would be suitable for human consumption or not. Only the tap water quality results were used in this section. The reason for this is a result of the limited number of water analyses conducted on the source and the wastewater sample points.

Only in the cases where determinants were measured were used in this discussion. Only one year's (2016) quality reports were used in the analyses due to unreliable data and different parameters tested from one year to another. The following parameters were analysed:

$p H$

The $\mathrm{pH}$ in water is the measurement to determine whether the water is acidic, alkaline or neutral. Although no health effects are associated with $\mathrm{pH}$, it plays an important role in the treatment of water, especially water clarification and disinfection. For effective disinfection with chlorine, the $\mathrm{pH}$ should preferable be less than eight (8) (DWAF 1996). The taste of water, its corrosive potential and the solubility and speciation of metal ions are all influenced by $\mathrm{pH}$. At a low $\mathrm{pH}$ water may taste sour, while at high $\mathrm{pH}$ water tastes bitter or soapy. The potential toxicity of metal ions and chemicals which can be protonated, for example ammonia, is influenced by $\mathrm{pH}$. Changes in $\mathrm{pH}$ affect the degree of dissociation of weak acids and bases (DWAF 1996). This effect is of special importance because the toxicity of many compounds are affected by their degree of dissociation. The $\mathrm{pH}$ results from the lodges in South Africa, Namibia and Botswana are illustrated in Figure 4.

The results state that the $\mathrm{pHs}$ of the water at all the lodges were compliant with the relevant countries' standard or guideline. Lodge S3, S4 and N7 all had pH levels above eight, meaning that slight treatment is required to ensure more efficient and successful disinfection. An interesting observation was that all the $\mathrm{pH}$ levels from Botswana were below six (slightly acidic), whereas the $\mathrm{pH}$ levels from South Africa and Namibia were all above seven. Carbon dioxide is a common cause of acidity in water and photosynthesis, respiration and decomposition all influence carbon dioxide levels. Considering the enormous amount of aquatic vegetation in the Okavango Delta, it is most likely the cause for the acidity in the Botswana water (DWAF 1996). 
Figure 4. pH Levels from Lodges in South Africa, Namibia and Botswana

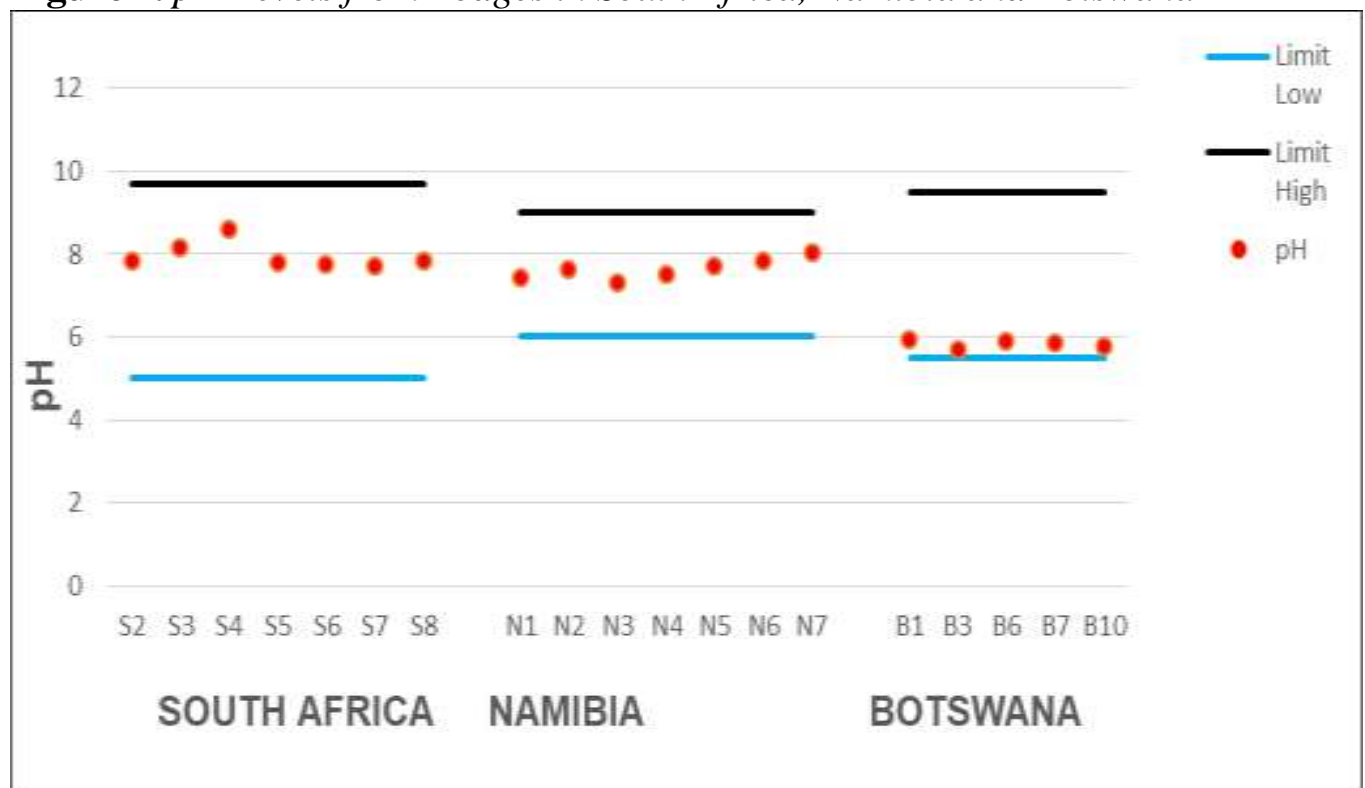

Source: Author.

Conductivity

Conductivity is the measurement to determine the transmission of electrical current in water and is an indicative of the total dissolved solids in the water. High conductivity can lead to a "mineral taste" in water and can cause severe scaling in piping and heating equipment such as geysers and kettles. No adverse health effects are associated directly to high conductivity (DWAF 1996). The results are illustrated in Figure 5.

Figure 5. Conductivity Levels from Lodges in South Africa, Namibia and Botswana

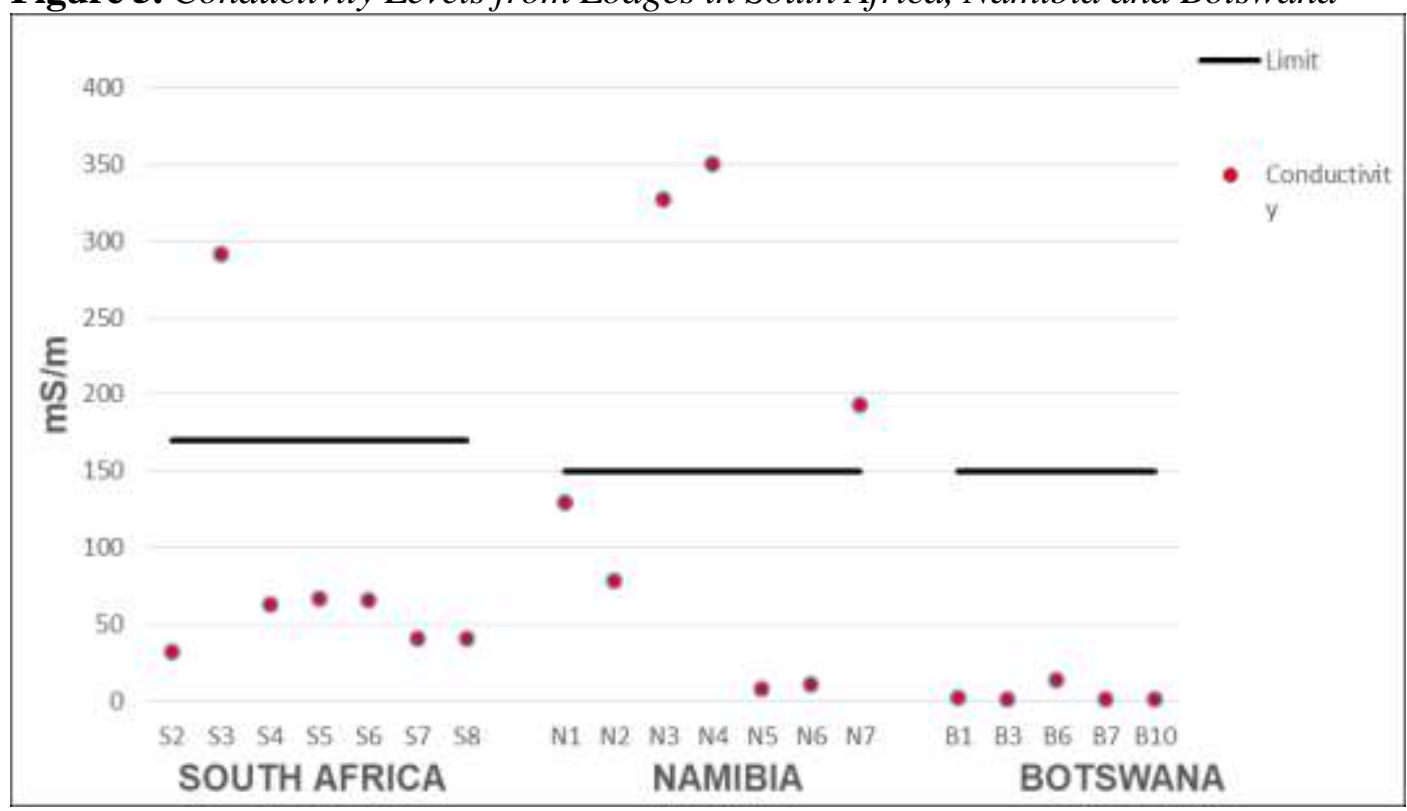

Source: Author. 
The results indicate that conductivity levels are within the relevant countries' standard or guideline, with the exception of lodge S3, N3, N4 and N7. The water from lodge S3 is unsuitable for human consumption based on the SANS 241: 2015 standard. Both lodge N3 and N4 were within category C of the Namibian guidelines, resulting that there is low health risk associated with conductivity levels in the water. Lodge N7 fell into category B, which states that the water is of acceptable quality, however not excellent.

\section{Total Dissolved Solids (TDS)}

The total dissolved solids (TDS) are a measure of the amount of various inorganic salts dissolved in water. The TDS concentration is directly related to the electrical conductivity of water. Since conductivity is much easier to measure than TDS, it is routinely used as an estimate of the TDS concentration. The Namibian standard does not provide a limit for TDS, most likely due to the direct relation with conductivity. The TDS results are illustrated in Figure 6.

The results indicate the relation between TDS and conductivity as the same lodges exceeded the standard limits. Although there is no limit for the Namibian lodges, since the conductivity exceeded the limit for lodge N3, N4 and N7, the same will apply for TDS. It can therefore be assumed that lodge N3 and N4 would be within category $\mathrm{C}$ of the Namibian guidelines, resulting that there is low health risk associated with the TDS levels in the water. Lodge N7 would fall into category B, which states that the water is of acceptable quality, however not excellent

Figure 6. TDS Levels from Lodges in South Africa, Namibia and Botswana

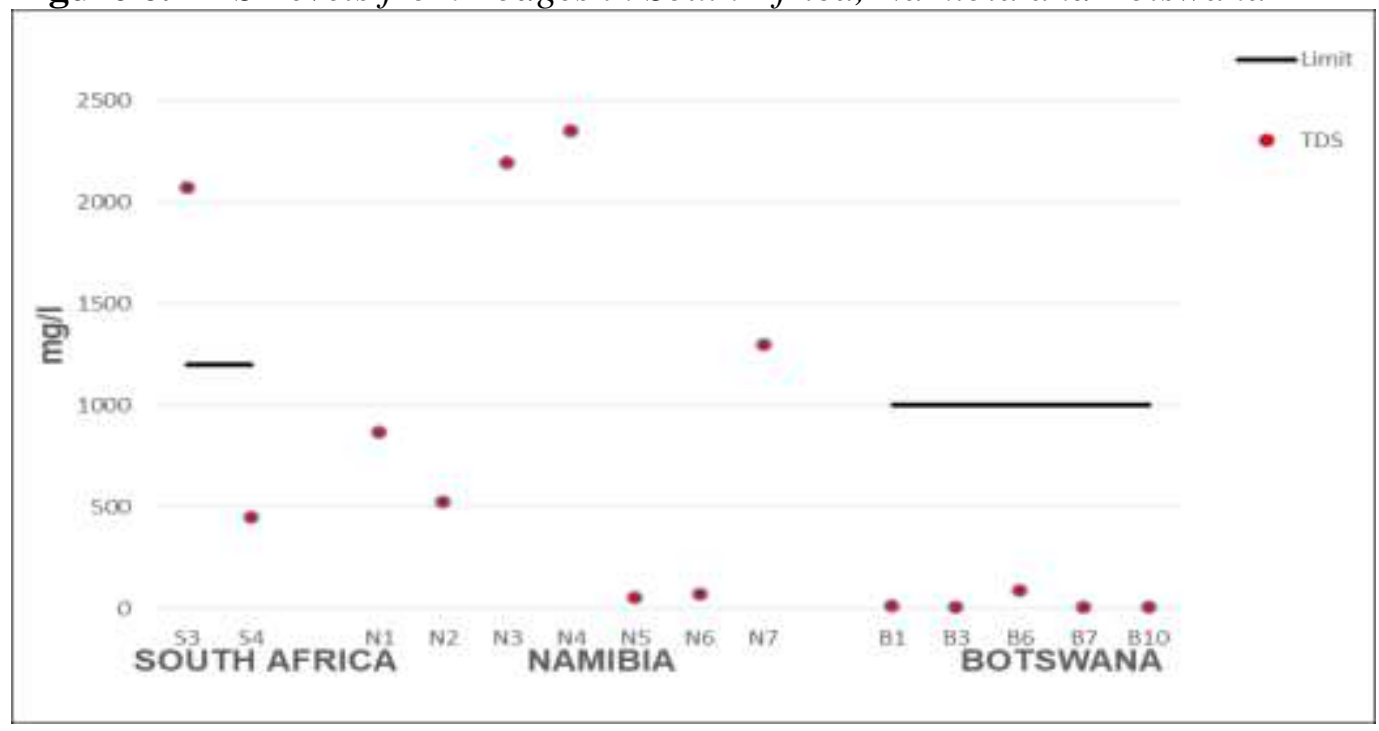

Source: Author.

Nitrate

Nitrate (NO3) are natural occurring ions that form part of the Nitrogen cycle. It is commonly used in inorganic fertilizers. It is also used as an oxidizing agent in 
the manufacturing of explosives and purified potassium nitrate is used for glass making. Sodium nitrite is used as a food preservative, especially in cured meats. Nitrate in water is undetectable without testing because it is colourless, odourless, and tasteless. Upon absorption, nitrate combines with the oxygen-carrying red blood pigment, haemoglobin, to form methaemoglobin, which is incapable of carrying oxygen. This condition is termed methaemoglobinaemia (DWAF 1996). The reaction of nitrate with haemoglobin can be particularly hazardous in infants under three months of age and is compounded when the intake of Vitamin $\mathrm{C}$ is inadequate. According to DWAF (1996) the effects of Nitrate are tabled in Table 4 below whereas the results are illustrated in Figure 7.

Table 4. The Effects of Nitrate on Human Health (DWAF 1996)

\begin{tabular}{|l|c|}
\hline $\begin{array}{l}\text { Nitrate range } \\
\text { as N mg/L }\end{array}$ & Effects \\
\hline $0-6$ & No adverse health effects \\
\hline $6-10$ & $\begin{array}{c}\text { Rare instances of methaemoglobinaemia in infants; no effects on } \\
\text { adults. Concentrations in this range generally well tolerated }\end{array}$ \\
\hline $10-20$ & Methaemoglobinaemia may occur in infants. No effects in adults \\
\hline$>20$ & $\begin{array}{r}\text { Methaemoglobinaemia occurs in infants. Occurrence } \\
\text { of mucous membrane irritation in adults }\end{array}$ \\
\hline
\end{tabular}

Source: Author.

Figure 7. Nitrate Levels from Lodges in South Africa, Namibia and Botswana

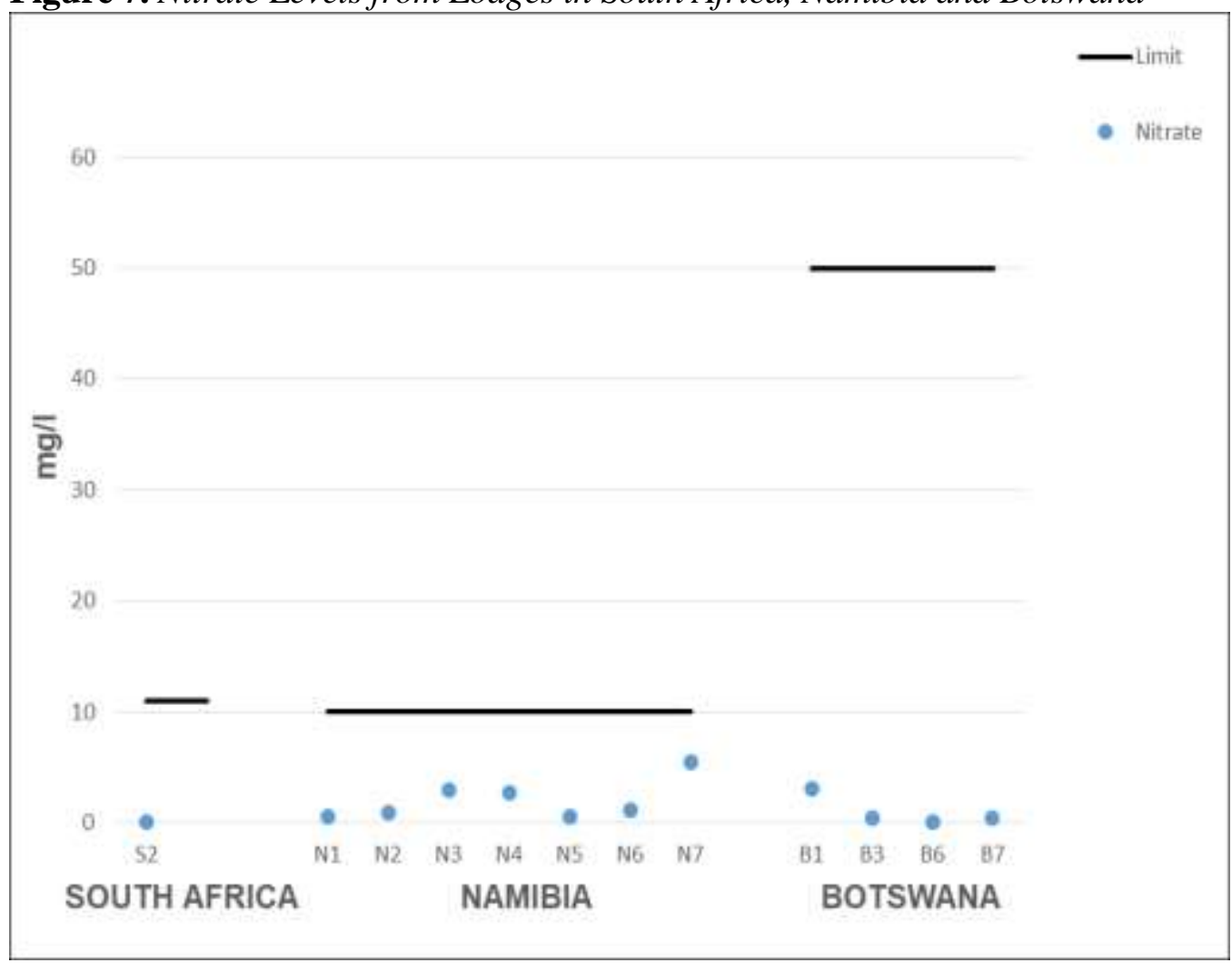

Source: Author. 
The results indicate that the Nitrate levels at all the lodges were well within the limit as per guidelines or standards. Only one lodge in South Africa (S2) had the Nitrate levels in their water analysed.

\section{Sulphate}

Sulphate (SO4) is the oxi-anion of the element Sulphur and occurs commonly in groundwater. As water moves through soil and rock formations that contain sulphate minerals, some of the sulphate dissolves into the groundwater. It is also an indication of pollution such as mine drainage and effluent return flows which contains high levels of Sulphate. High levels of Sulphate can give water a bitter or astringent taste and can have adverse health effects, causing diarrhoea. Sulphate accelerates corrosion in piping and can cause metals to leach into the water (DWAF 1996). According to DWAF (1996), Table 5 below state the effects of Sulphate on aesthetics and human health whereas Figure 8 illustrates the results.

Table 5. The Effects of Sulphate on Aesthetics and Human Health (DWAF 1996)

\begin{tabular}{|l|c|}
\hline $\begin{array}{l}\text { Sulphate range as SO4 } \\
\text { mg/L }\end{array}$ & \multicolumn{1}{c|}{ Effects } \\
\hline $0-200$ & No health or aesthetic effects are experienced \\
\hline $200-400$ & $\begin{array}{c}\text { Tendency to develop diarrhoea in sensitive and some } \\
\text { non-adapted individuals. Slight taste noticeable }\end{array}$ \\
\hline $400-600$ & $\begin{array}{c}\text { Diarrhoea in most non-adapted individuals. Definite } \\
\text { salty or bitter taste }\end{array}$ \\
\hline $600-1000$ & $\begin{array}{c}\text { Diarrhoea in most individuals. User-adaptation does not } \\
\text { occur. Pronounced salty or bitter taste }\end{array}$ \\
\hline$>1000$ & $\begin{array}{c}\text { Diarrhoea in all individuals. User-adaptation does not } \\
\text { occur. Very strong salty and bitter taste }\end{array}$ \\
\hline
\end{tabular}

Source: Author.

Figure 8. Sulphate Levels from Lodges in South Africa, Namibia and Botswana

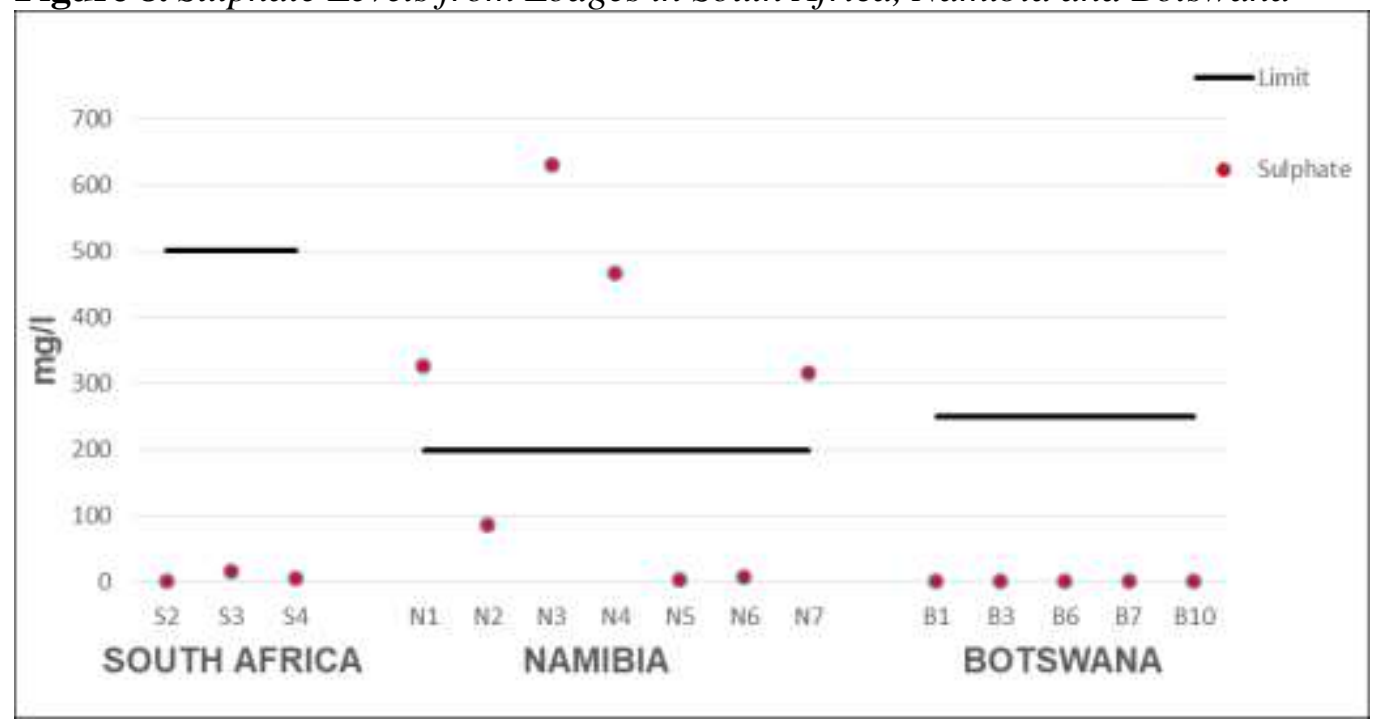

Source: Author. 
The results indicate that the lodges that did test for sulphate levels in South Africa and Botswana were well within the limit of the relevant standards. The majority of the lodges in Namibia exceed the category A limit. Although the sulphate levels from lodge N1, N4 and N7 falls within category B (acceptable water quality) of the Namibian standard, Table 5 above suggest that diarrhoea may occur in sensitive and non-adapted users. The sulphate level from lodge N3 fell within category $\mathrm{C}$, which relates to a low health risk associated with the sulphate level and according to Table 5 may lead to diarrhea.

Iron

Pure iron is silvery in colour but usually appears as greyish black or brown deposits as a result of oxidation. Biologically iron is an essential micronutrient required by all living organisms. High concentrations of iron are predominantly an aesthetic concern since ferrous salts are unstable under the $\mathrm{pH}$ conditions prevailing in drinking water and precipitate as insoluble ferric hydroxide, which settles out as a rust-coloured silt. Excessive ingestion of iron may result in haemochromatosis, wherein tissue damage occurs as a consequence of iron accumulation. Haemochromatosis generally results from prolonged consumption of acid foodstuffs cooked in kitchenware made of iron. Poisoning is rare since excessively high concentrations of iron do not occur naturally in water. The extreme unpalatability of such water would probably prevent consumption. Further, iron in the distribution system promotes proliferation of iron-oxidising bacteria which oxidise ferrous iron to ferric iron, and manifest as slimy coatings in plumbing when the iron concentration of the water in the distribution system approaches $0.3 \mathrm{mg} / \mathrm{L}$. Effects are predominantly aesthetic, such as the staining of enameled surfaces of baths, hand basins and lavatory cisterns/bowls and laundry (DWAF 1996). According to DWAF (1996) the effects of Iron are stated in Table 6 below whereas the results are illustrated in Figure 9.

Table 6. Effects of Iron on Aesthetic and Human Health (DWAF 1996)

\begin{tabular}{|c|c|}
\hline $\begin{array}{l}\text { Iron } \\
\text { range as } \\
\text { Fe mg/L }\end{array}$ & Effects \\
\hline $0-0.1$ & $\begin{array}{c}\text { No taste, other aesthetic or health effects associated with consumption and } \\
\text { use. }\end{array}$ \\
\hline $1-3$ & $\begin{array}{l}\text { Very slight effects on taste and marginal other aesthetic effects. Deposits in } \\
\text { plumbing with associated problems may begin to occur. No health effects; the } \\
\text { water is generally well tolerated }\end{array}$ \\
\hline $3-10$ & $\begin{array}{l}\text { Adverse aesthetic effects (taste) gradually increase as do possible problems } \\
\text { with plumbing. No health effects }\end{array}$ \\
\hline $10-100$ & $\begin{array}{l}\text { Pronounced aesthetic effects (taste) along with problems with plumbing. } \\
\text { Slight health effects expected in young children, and sensitive individuals }\end{array}$ \\
\hline $\begin{array}{l}100- \\
300\end{array}$ & $\begin{array}{l}\text { Severe aesthetic effects (taste) and effects on the plumbing (slimy coatings). } \\
\text { Slight iron overload possible in some individuals. Chronic health effects in } \\
\text { young children and sensitive individuals in the range } 100-200 \mathrm{mg} / \mathrm{L} \text {, and } \\
\text { occasional acute effects toward the upper end of this range. }\end{array}$ \\
\hline
\end{tabular}

Source: Author. 
Figure 9. Iron Levels from Lodges in South Africa, Namibia and Botswana

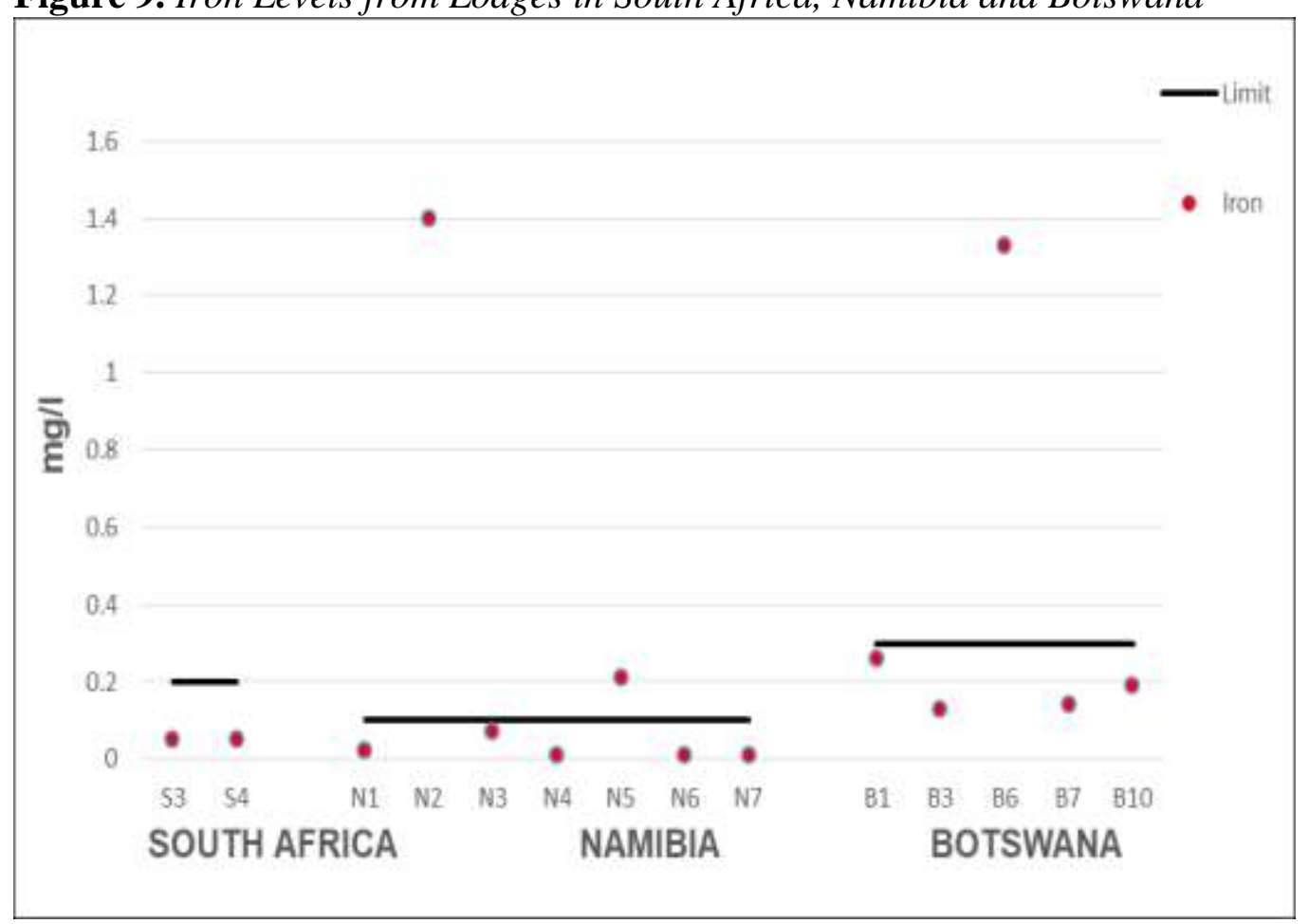

Source: Author.

The results indicate that all the lodges that tested for Iron, with the exception of lodge N5 (category B, acceptable water quality), N2 (category C, low health risk) and B6 (not fit for human consumption), the levels were within the relevant standards or guidelines.

\section{Chloride}

Chloride is the negative ion (anion) of the element Chlorine and is commonly found in ground water. It generally combines with calcium, magnesium, or sodium to form various salts such as sodium chloride $(\mathrm{NaCl})$. Although chlorides are harmless at low levels, groundwater with high levels of sodium chloride can damage vegetation if used for gardening or irrigation, and give drinking water an unpleasant taste. Over time, sodium chloride's high corrosion properties will also damage plumbing, appliances, and water heaters, causing toxic metals to leach into the water (DWAF 1996). Chloride toxicity has not been observed in humans except in special cases of impaired sodium chloride metabolism, e.g. in congestive heart failure. Healthy individuals can tolerate the intake of large quantities of chloride provided that there is a concomitant intake of fresh water. According to DWAF (1996) the effects of Chloride on aesthetics, household distribution systems and appliances and human health are stated in Table 7 whereas the results are illustrated in Figure 10. 
Table 7. The Effects of Chloride on Aesthetics, Household Distribution Systems and Appliances and Human Health (DWAF, 1996)

\begin{tabular}{|l|c|}
\hline $\begin{array}{l}\text { Chloride } \\
\text { range mg/L }\end{array}$ & Effects \\
\hline $0-100$ & $\begin{array}{c}\text { No aesthetic or health effects. The threshold for } \\
\text { corrosion acceleration in domestic appliances is at } 50 \mathrm{mg} / \mathrm{L}\end{array}$ \\
\hline $100-200$ & $\begin{array}{c}\text { No aesthetic or health effects. Possible increase in the corrosion rate in } \\
\text { domestic appliances }\end{array}$ \\
\hline $200-600$ & $\begin{array}{c}\text { Water has a distinctly salty taste, but no health effects Likelihood of } \\
\text { noticeable increase in corrosion rates in domestic appliances }\end{array}$ \\
\hline $600-1200$ & $\begin{array}{c}\text { Water has objectionable salty taste and will not slake thirst. Likelihood } \\
\text { of rapid corrosion in domestic appliances }\end{array}$ \\
\hline$>1200$ & $\begin{array}{c}\text { Water unacceptably salty. Nausea and disturbance } \\
\text { of the electrolyte balance can occur, especially in infants, where } \\
\text { fatalities due to dehydration may occur. }\end{array}$ \\
\hline
\end{tabular}

Source: Author.

Figure 10. Chloride Levels from Lodges in South Africa, Namibia and Botswana

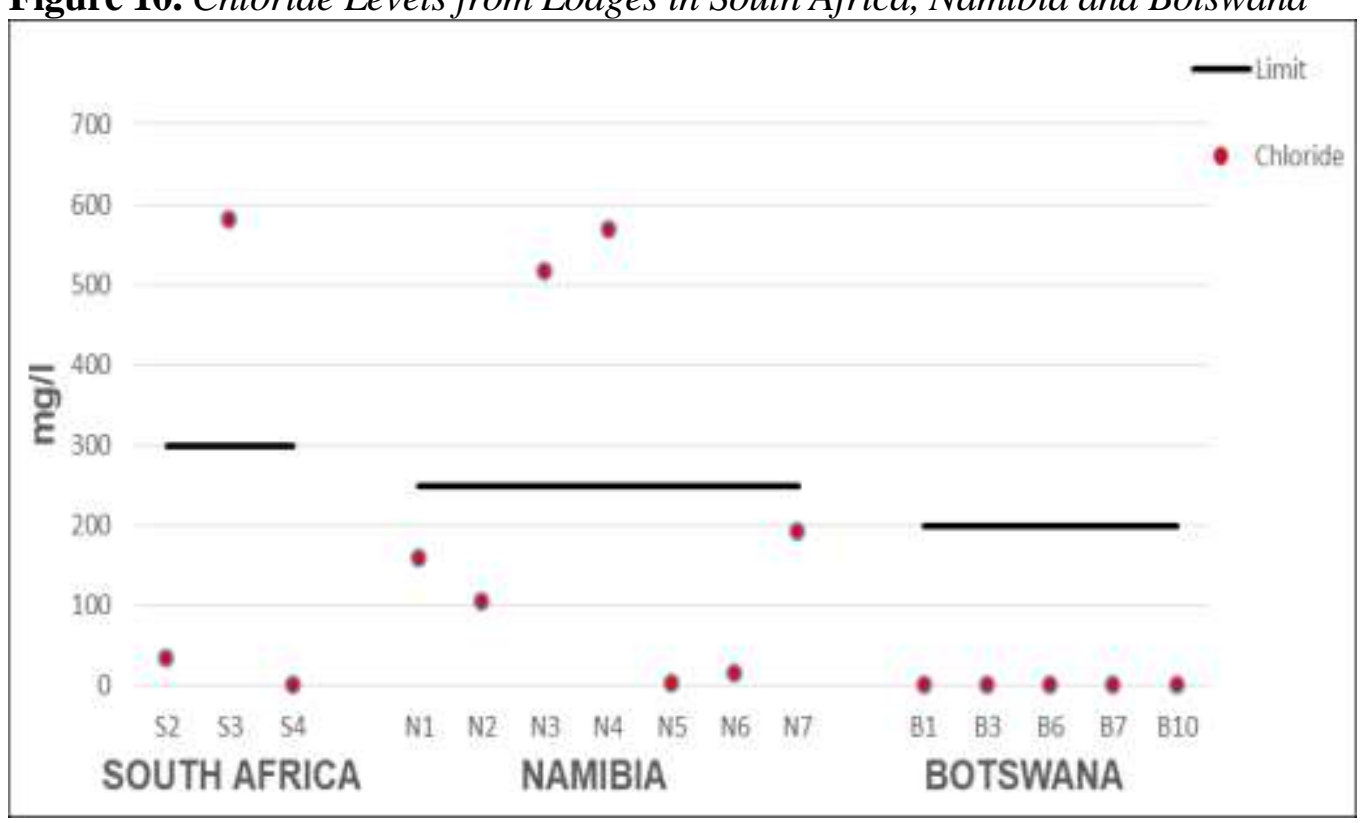

Source: Author.

The results indicate that the chloride levels at most of the lodges were within the relevant standards or guidelines. Although the chloride levels from lodge N3 and N4 were outside category A, it still fell within category B resulting in accepted water quality. The water from lodge S3 is unsuitable for human consumption in South Africa due to the SANS 241: 2015 limit. The chloride levels at all the lodges in Botswana were well within the limit.

\section{Escherichia coli (E coli)}

Escherichia coli, more commonly known as only $E$ coli, is a bacteria that origins from the faeces of humans and other warm blooded animals. Many 
different strains of $E$ coli exist and more than 700 serotypes have been identified. The most common and dangerous serotype is E coli $0157:$ H7. Common diseases associate with $E$ coli is gastrointestinal infections, diarrhoea, nausea and vomiting. In some people, particularly children under 5 years of age and the elderly, the infection can also cause a complication called hemolytic uremic syndrome, in which the red blood cells are destroyed and the kidneys fail. About $2 \%-7 \%$ of infections lead to this complication. Symptoms usually appear within 2 to 4 days, but can take up to 8 days. Water containing $E$ coli can be easily disinfected by adding Calcium hypochlorite (swimming pool chlorine) or Sodium hypochlorite (chlorine bleach) (DWAF, 1996). Another method to eliminate $E$ coli is through an ultra violet (UV) light. The results are illustrated in Figure 11.

Figure 11. E coli Results From Lodges in South Africa and Botswana

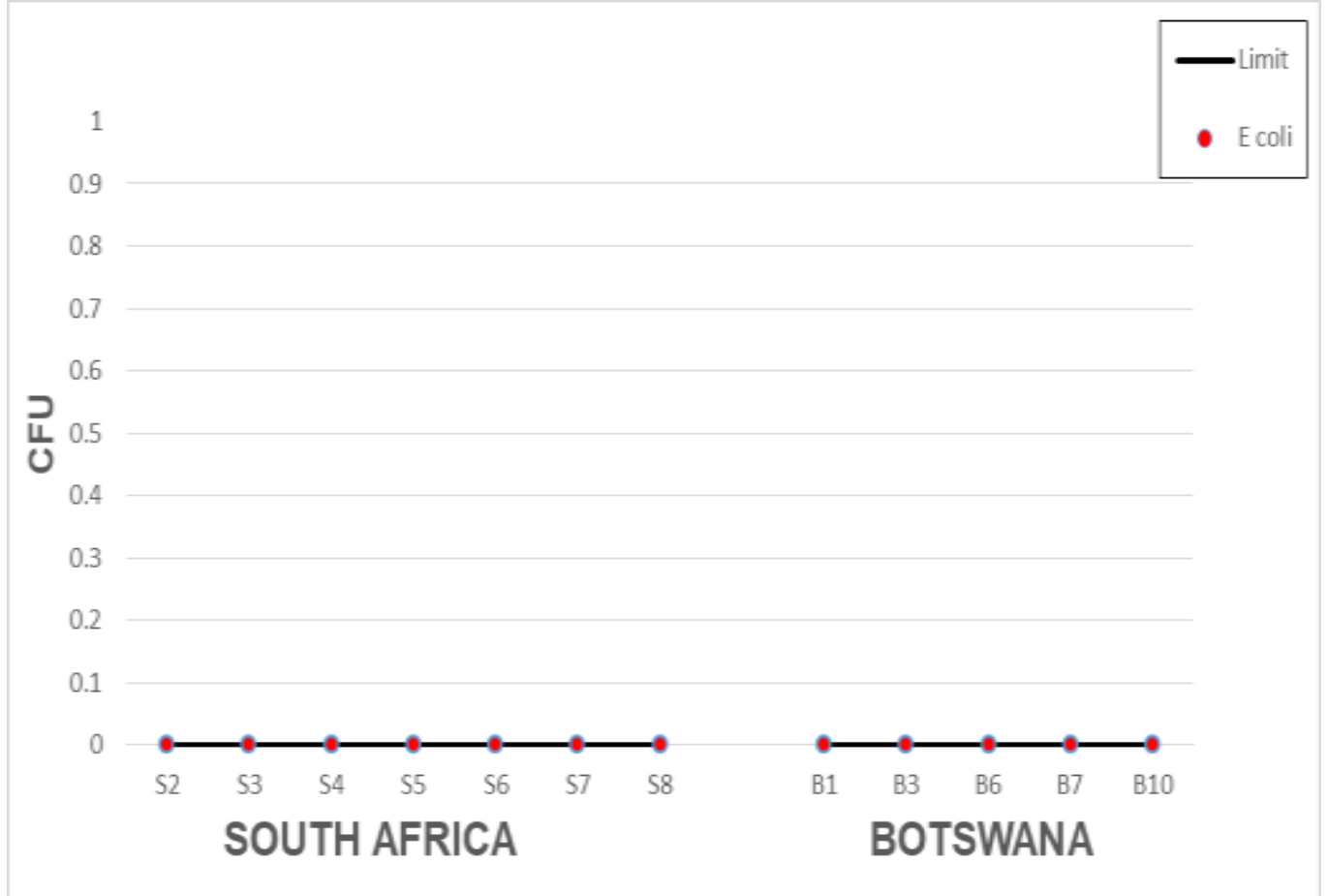

Source: Author.

The results indicate that no $E$ coli were detected at any lodges that tested for the bacteria, resulting in complying with the relevant standards. None of the lodges in Namibia had their water tested for the presence of $E$ coli.

\section{Total Coliforms}

Coliform bacteria are a natural part of the microbiology of the intestinal tract of warm blooded mammals, including man. Coliform bacteria can also be found in soil, other animals, insects, etc. Total coliform bacteria refer to all bacteria which produce colonies with a typical metallic sheen within 20 -24 hours of incubation at $35^{\circ} \mathrm{C}$. These tests provide an indication of the general sanitary quality of water since many of the bacteria in this group are from faecal origin. If large numbers of 
coliforms are found in water, there is a high probability that other pathogenic bacteria or organisms, such as Giardia and Cryptosporidium, may be present. Water containing coliforms can be easily disinfected by adding Calcium hypochlorite (swimming pool chlorine) or Sodium hypochlorite (chlorine bleach). Another method to eliminate coliform bacteria is through an ultra violet (UV) light. The results are illustrated in Figure 12.

Figure 12. Total Coliform Results from Lodges in South Africa, Namibia and Botswana

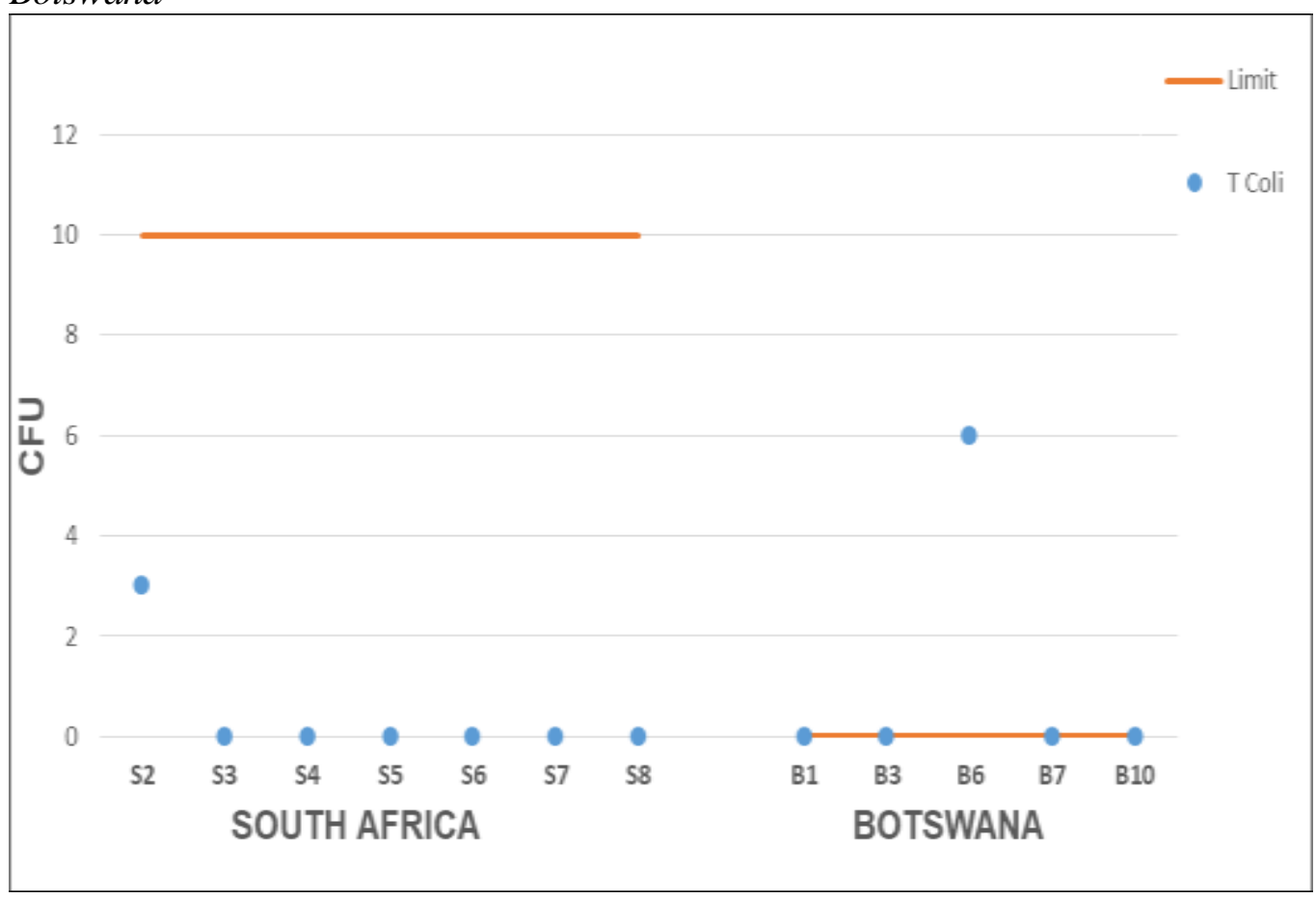

Source: Author.

The results indicate that coliform bacteria were detected at lodge S2 as well as B6. The limit in South Africa for coliform bacteria is $10 \mathrm{CFU}$, meaning that the water from lodge $\mathrm{S} 2$ is still suitable for consumption. In Botswana the limit is 0 and therefore the water at lodge B6 does not comply with the standard requirements. No coliform bacteria were detected at any of the other lodges.

\section{Conclusion and Recommendations}

The results indicate that $88 \%$ of the lodges in South Africa do engage in water quality analysis of their tap water, however, only $25 \%$ of those lodges tested more than $26 \%$ of the relevant standard of their drinking water. There is thus no certainty in concluding that the lodge water quality is safe for human consumption at those the lodges in South Africa regardless if the parameters tested comply with limits. The same applies for Namibia as well as Botswana. In Namibia there were no microbiological tests and in Botswana only $28 \%$ of the required parameters 
were tested. Although many lodges supply their guests with bottled water, the concern is the water supply to the staff. In South Africa, staff residing on the premises trigger section 8 of the National Occupation Health and Safety act, which states: "Every employer shall provide and maintain, as far as is reasonably practicable, a working environment that is safe and without risk to the health of his employees". It is therefore highly recommended that the lodges in all three countries engage in more conclusive and more frequent water quality testing to ensure the safety of their staff as well as guests.

Although the $\mathrm{pH}$ levels at all the lodges were within the limits, it is recommended that the lodges treat the $\mathrm{pH}$ to be as close to 7 as possible, especially the lodges the $\mathrm{pH}$ levels of above 8 . This will ensure more effective treatment of the water especially with regards to disinfecting the water. Digital $\mathrm{pH} / \mathrm{TDS}$ combo meters can be bought for less than $\mathrm{R} \mathrm{500.} \mathrm{This} \mathrm{will} \mathrm{allow} \mathrm{the} \mathrm{lodges} \mathrm{to}$ monitor the $\mathrm{pH}$ levels themselves and will ensure that the $\mathrm{pH}$ can be monitored more regularly.

The conductivity and TDS in the water at the majority of the lodges were within the limits. The high conductivity levels will affect the taste of the water and could cause damage to piping and heating elements. The most common way to reduce TDS and conductivity is through a reverse osmosis system. Other alternatives are distillation and de-ionizing.

The nitrate levels at the lodges were all within the required limits and do not require any treatment. Several lodges had issues with Iron, Sulphate and Chloride levels. Iron can be treated by an oxidizing process which will removed the particles through filtration. This can be achieved by devices such as fountains or chemically oxidized by dosing the water with chlorine or hydrogen peroxide. Chloride levels can be lowered through electrolysis or desalination techniques such as reverse osmosis. Desalination will also be effective to treat the high Sulphate levels (DWAF 1996).

Although $E$ coli were absent at all the lodges, two lodges had small amounts of coliform bacteria in their water. This can be treated by adding disinfectants such as Calcium hypochlorite (swimming pool chlorine) or Sodium hypochlorite (chlorine bleach). Since this is such an important parameter, it is recommended that the lodges test for bacteria regularly. Test kits can be purchased for less than $\mathrm{R}$ 600 and will give accurate results with regards to bacteria in the water.

\section{References}

Baoying N, Yuanqing H (2007) Tourism Development and Water Pollution: Case Study in Lijiang Ancient Town. China Population, Resource and Environment 17(5): 23127.

Frankiln B (1746) Poor Richards almanac. New York: Century Co.

Gleditsch NP (1997) Conflict and the environment. Netherlands: Springer.

Gössling S, Peeters P, Hall CM, Ceron JP, Dubois G, Lehmann LV, Scot D (2012) Tourism and Water use: Supply, Demand and Security. An International Review. Tourism Management 33(1): 1-15. 
Gössling S, Hall CM, Scott D (2015) Tourism and Water. Ontario: Channel View Publications.

Howard G, Bartram J (2003) Domestic Water Quantity, Service and Health. Geneva: World Health Organization.

Khan S, Shahnaz M, Jehan N, Rehman S, Shah MT, Din I (2013) Drinking water quality and human health risk in Charsadda district, Pakistan. Journal of Cleaner Production 60(1): 93-101.

Kuss FR, Graefe AR, Vaske JJ (1990) Visitor Impact Management. A Review of Research National Parks and Conservation Association. Washington, DC.

Serageldin I (2009) Water: Conflicts set to arise within as well as between states. Nature 459:163.

South African Bureau of Standards [SABS] (2015) South African National Standard (241) for drinking water. Pretoria: SABS.

Walmsley B, Patel S (2011) Handbook on Environmental Assessment Legislation in the SADC Region ( $3^{\text {rd }}$ edition). Pretoria: Development Bank of Southern Africa (DBSA) in collaboration with the Southern African Institute for Environmental Assessment (SAIEA). 